\title{
University of California
}

Agriculture and Natural Resources

DAVID M. CROHN, UC Cooperative Extension biological systems engineer and associate professor, Department of Environmental Science, UC Riverside.

\section{Assessing Compost Quality for Agriculture}

\section{Abstract}

omposts are widely used as organic amendments to add organic matter and nutrients to soils and are also sometimes used as mulches to control pests and conserve water. Compost quality can be evaluated through laboratory analysis, but the measurable properties used to evaluate composts are different from those used to describe the soils to which they are added. Parameters such as the carbonto-nitrogen $(\mathrm{C}: \mathrm{N})$ ratio, organic matter content, salinity, total nitrogen, total phosphorus, stability, phytotoxicity, $\mathrm{pH}$, maturity, boron, chloride, sodium, particle sizes, heavy metal concentration, and pathogen concentrations are factors to evaluate when you are comparing available compost products. This publication describes each of these measures and proposes reasonable limits for five common types of compost application, including use as a soil amendment for strawberries, canning tomatoes, and lettuce as well as mulch use for grapes and avocados. A new estimation method will also help you predict the short-term influence of composts on soil salinity.

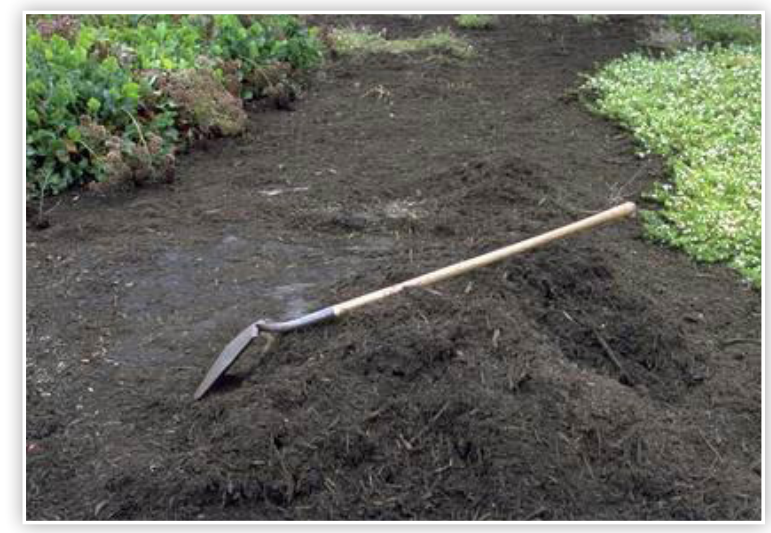

\section{Acknowledgments}

The information presented here was derived from a project funded by CalRecycle. Dan Noble of the Association of Compost Producers assisted in management of the project. Ron Alexander shared his deep knowledge of compost quality specifications. Frank Shields of the Soil Control Lab shared his database of typical organic amendment measurements. Ludmilla Kuzina assisted in collecting literature and surveying farm advisors for their opinions regarding what parameters should be used to characterize compost quality in California. 


\section{Introduction}

When incorporated into a soil, compost acts as a soil amendment. When applied to the soil surface and not incorporated, it serves as a mulch. In their soil amendment role, composts improve fertility and tilth, while as mulches they can reduce erosion, conserve water, control weeds, and manage pests. Before you can evaluate the suitability of a compost for a particular application, you need to have an understanding of several compost properties-which differ significantly from soil qualities you may be familiar with. The compost industry uses a suite of analytical tests known as the TMECC (Test Methods for the Examination of Composting and Compost) to characterize compost products (Leege 1998). The Seal of Testing Assurance (STA) is awarded to composts that have been sampled and tested by a certified laboratory according to these methods.

As you read on, you will see how you can interpret compost properties, as reported in official industry reports, and use them as a basis for selecting products that are likely to be appropriate for your particular growing conditions. Examples are provided for five representative crops, including compost soil amendments for lettuce, canning tomatoes, and strawberries, and compost mulches for avocado and grapes. (Some grape and avocado growers apply compost as a side dressing to quickly increase soil organic matter and are less interested in the benefits of compost used as a mulch. In such a case, it is appropriate for them to choose a compost with properties more appropriate for soil amendment usage.) The parameters included here were selected by the author after a survey of UC Cooperative Extension Farm Advisors to see what issues they considered to be of most concern with regard to each specific crop.

The cost for transporting compost can be considerable, so the proximity of a farm to possible sources of compost will strongly influence a grower's sense of what compost products are available economically for use. This publication presents appropriate ranges for many of the compost properties considered. The parameter limits presented here should be considered as

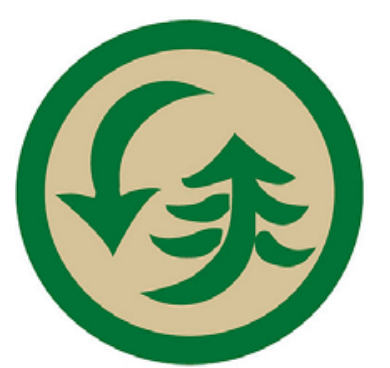

US Compositing Seal of Testing Assurance $^{\circ}$

Figure 1. This symbol on a compost product attests that the compost has been sampled and tested in accordance to the U.S. Composting Council's STA program.

rough suggestions and not as absolute limits. It is reasonable for a grower to consider other factors, including price, transportation costs, soil conditions, water quality, application rates, soil leaching capabilities, the time between compost incorporation and planting, intended uses, and personal experiences, when making a purchase decision.

\section{C:N Ratio}

When soil microbes decompose a compost, they use its carbon (C) for energy while immobilizing some nitrogen $(\mathrm{N})$ to meet their own needs. Immobilized $\mathrm{N}$ is temporarily unavailable to plants until such time as those microbes themselves decompose. The carbon-to-nitrogen (C:N) ratio is roughly proportional to the balance between the overall energy contained in the compost (which corresponds to its carbon content) and the principal nutrient needed to decompose it, nitrogen, expressed as the total compost $\mathrm{C}$ divided by the total compost $\mathrm{N}$. Composts with a higher $\mathrm{C}: \mathrm{N}$ ratio generally immobilize more $\mathrm{N}$ for longer periods of time. Immobilization is less significant in a stable compost, since soil microbes will metabolize the carbon in stable composts slowly. Uncomposted materials that are unstable and have a high C:N ratio are more likely to pose problems, since composting is a stabilizing process that eliminates the bulk of readily available carbon. LowC:N composts $(\mathrm{C}: \mathrm{N}<20: 1)$ may be expected to gradually mineralize nitrogen with little or no immobilization (Bruun et al. 2006; Paul 
Figure 2. Wood chips have a high C: $\mathrm{N}$ ratio (on the order of 600:1), while dairy manures have a lower ratio (on the order of

15:1). Of the two, woody composts decompose more slowly, but manurebased products supply more nitrogen.
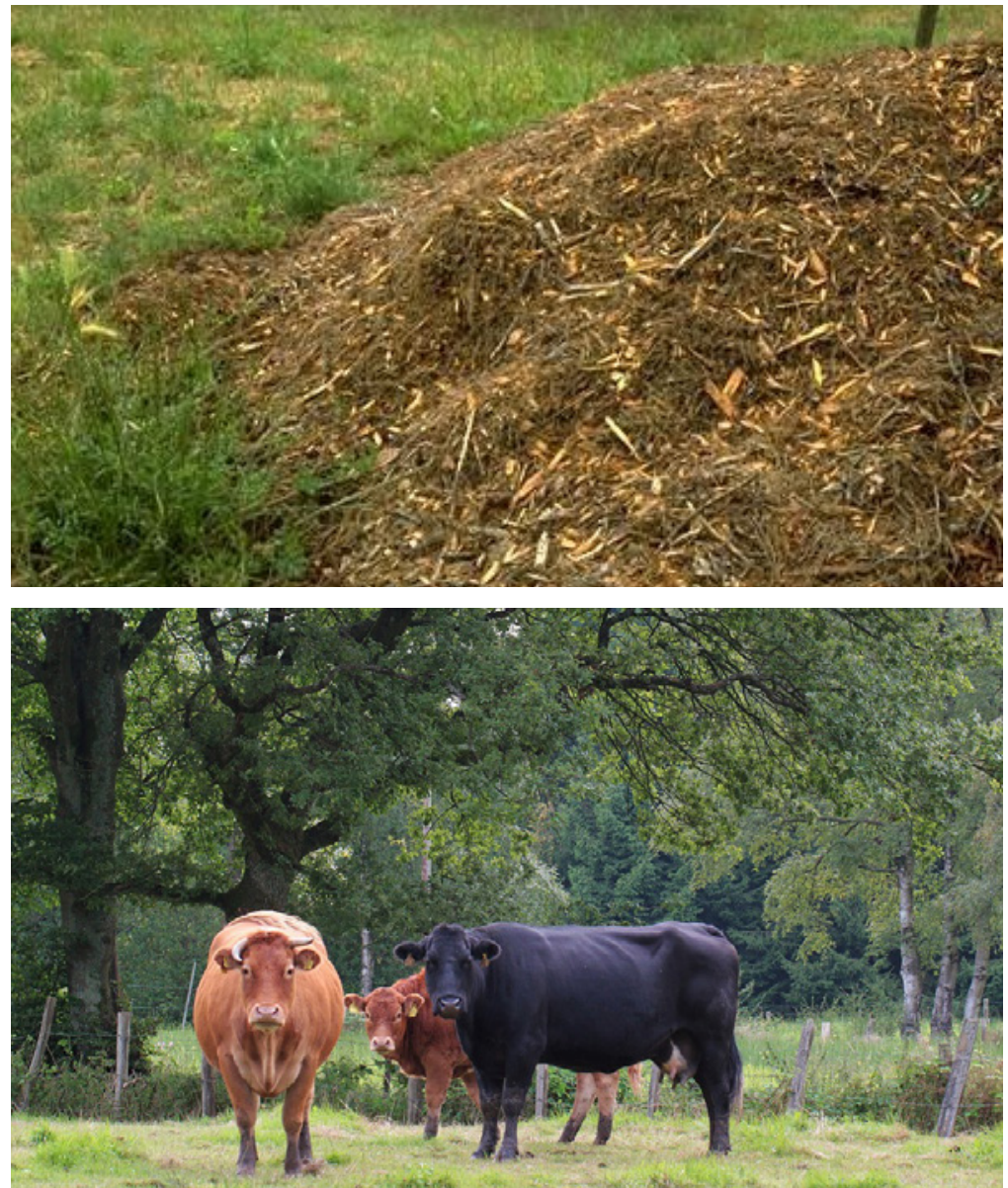

2007). Lower-C:N materials $(<10: 1)$ are often composed of relatively labile feedstock, such as manures, biosolids, or food wastes. Because decomposer microbes work more quickly when warm, both nitrogen mineralization and immobilization are accelerated during the summer.

A higher C:N ratio (>25:1) in a stable compost can imply the presence of lignin that resists decay. Mulches used to control weeds and conserve water should resist decomposition since they are applied on the soil surface. Mulch is not normally applied as a
Table 1. C:N ratio limits

\begin{tabular}{|l|c|}
\hline Use & C:N ratio \\
\hline Mulch & $\geq 15: 1$ \\
\hline Soil amendment & $\leq 20: 1$ \\
\hline
\end{tabular}

source of nitrogen for plants, so higher $\mathrm{C}: \mathrm{N}$ ratios are acceptable for these materials. Higher C:N ratios (>40:1) also limit the nutrients available to weeds. Low-C:N composts are appropriate for use as soil amendments, which are mixed into in the root zone where nutrient availability is crucial for crop success. Fine-textured lowC:N composts work well as mulch if you mean to encourage rapid re-vegetation to reduce erosion from setbacks or similar waterprotection structures (Crohn et al. 2013), but they usually are not desirable for use as an agricultural mulch since they encourage weed development.

\section{Organic Matter}

Organic matter plays a critical role in establishing and maintaining both soil structure and fertility. It also serves a vital role in maintaining a healthy soil ecology (Paul 2007). California soils tend to be low in organic matter and supplementation is a principal purpose of compost application. Growers should make note of the organic matter content of potential soil amendments when comparing the price and qualities of different composts; most composts are between 25 and 75 percent organic matter. Composts that contain large amounts of inert materials, such as soil, silica, or ash, will not provide as many benefits as a compost that is richer in organic materials.

For soil amendments, however, an upper limit of 65 percent organic matter is commonly imposed, since materials with a greater organic matter content may not be fully stable. Such an upper limit is not appropriate for compost mulches, though, since in most cases the majority of their organic content is wood, which degrades slowly in the soil. Furthermore, composts are less reactive with the soil when placed on top of it (as a mulch) than when incorporated into the soil (Ron Alexander, personal communication 2013). 


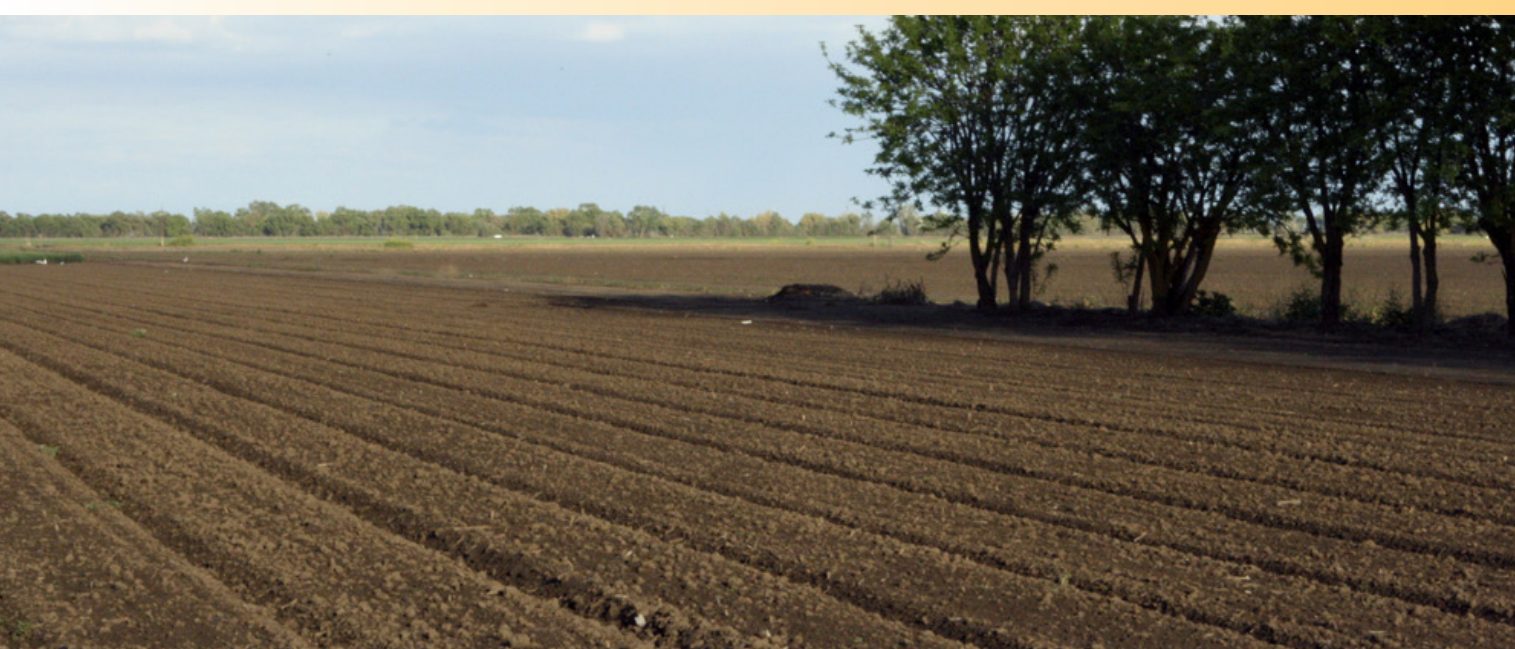

Figure 3. Low-organic-matter composts usually contain a good deal of soil. It takes twice as much material for a 25 -percent-organic-matter compost to provide the same conditioning benefits as a given amount of 50-percent-organic-matter compost.

Table 2. Organic matter

\begin{tabular}{|l|c|}
\hline Use & Organic matter \\
\hline Mulch & $\geq 25 \%$ \\
\hline Soil amendment & $\geq 25 \%$ \\
& $\leq 65 \%$ \\
\hline
\end{tabular}

\section{Salinity (EC)}

Salinity can have both specific and nonspecific effects on crop development. In a nonspecific effect, dissolved ions create an osmotic gradient that prevents plants from obtaining the nutrients and water they need. A specific effect is when the plant takes up particular ions in excess of their nutrient value-the excess can be toxic in its own right or can cause toxicity indirectly, as when a salt having limited or no nutritional value displaces more vital nutrients in the plant (Shannon and Grieve 1998).

Electrical conductivity (EC) is an accurate, indirect means of measuring salinity in soils. When documenting and managing soil characteristics, growers and consultants most often measure soil salinity levels (table 3 ) as $\mathrm{EC}_{\text {e, }}$ the electrical conductivity of water extracted from a saturated paste of the soil. Conductivity is measured in units of deciSiemens per meter $(\mathrm{dS} / \mathrm{m})$, or sometimes milliSiemens per centimeter $(\mathrm{mS} / \mathrm{cm})$, which works out to have the same numerical value as $\mathrm{dS} / \mathrm{m}$. Older records and literature may give EC values in millimhos per centimeter $(\mathrm{mmhos} / \mathrm{cm})$, which is also equivalent to $\mathrm{dS} / \mathrm{m}$ or $\mathrm{mS} / \mathrm{cm}$. A saturated paste of the soil is used for measurement since it seems to accurately represent the influence of salinity on plant roots. Because it is difficult to locate precise saturation points in a compost, compost salinity is measured as $\mathrm{EC}_{5}$, using extracts from a 5:1 water-to-compost mixture.

Composts with elevated EC values can be especially rich in nutrients, since nutrients are responsible for much of the measured conductivity. All charged ions that enter the soil solution contribute to EC measures. Some, like nitrate, ammonium, and potassium, are important macronutrients whose presence in compost reduces the need for additional fertilizers. Other ions, such as sodium and chloride, represent a concern for soil and plant health if they are present at elevated concentrations. This suggests that salinity increases that result from compost use are less of a matter for concern than salinity increases attributable to other factors, such as irrigation water quality. Experiments have demonstrated, however, that the nonspecific effect of compost salinity is similar in magnitude to nonspecific effects from other sources and that use of published $\mathrm{EC}_{\mathrm{e}}$ tables derived for irrigation water and soil management are also appropriate for evaluating soil-compost mixtures. It should be noted that non-specific salinity effects are generally offset by the benefits of compost use (Reddy and Crohn 2012).

Compost $\mathrm{EC}_{5}$ and soil $\mathrm{EC}_{\mathrm{e}}$ values are not directly comparable, though an $\mathrm{EC}_{5}$ value will be less than a corresponding $\mathrm{EC}_{\mathrm{e}}$ value, all things being equal. Estimation of the likely impact of a compost on soil $\mathrm{EC}_{\mathrm{e}}$ requires information on the compost application rate in tons per acre, along with soil's texture, organic matter content, and pre-compost $\mathrm{EC}_{\mathrm{e}}$ (Reddy and Crohn 2012). A spreadsheet tool is available for this purpose (figure 4). Evidence shows that crops perform best if soil EC $\mathrm{E}_{\mathrm{e}}$ levels are below crop-specific salinity thresholds (table 3). The estimates can be compared to the crop salinity thresholds as shown in table 3 to determine whether leaching will be necessary to reduce $\mathrm{EC}_{\mathrm{e}}$ levels. 
Table 3. Soil salinity $\left(\mathrm{EC}_{\mathrm{e}}\right)$ thresholds

\begin{tabular}{|l|c|}
\hline Crop & $\begin{array}{c}\text { Concentration in } \\
\text { saturated extract }\end{array}$ \\
\hline Avocado & $\mathrm{dS} / \mathrm{m}$ \\
\hline Lettuce & $4^{*}$ \\
\hline Tomato & 1.3 \\
\hline Grape & 2.5 \\
\hline Strawberry & 1.5 \\
\hline
\end{tabular}

SOURCE: Hanson et al. 1993; Maas 1986

* Avocado value represents a toxicity threshold reported by UC academics.

\section{Figure 4. Spreadsheet tool for estimating the $\mathrm{EC}_{\mathrm{e}}$ of soil-compost mixtures. \\ (Double-click on paperclip symbol to reach Excel spreadsheet. Requires Adobe Acrobat Reader and Microsoft Excel.)}

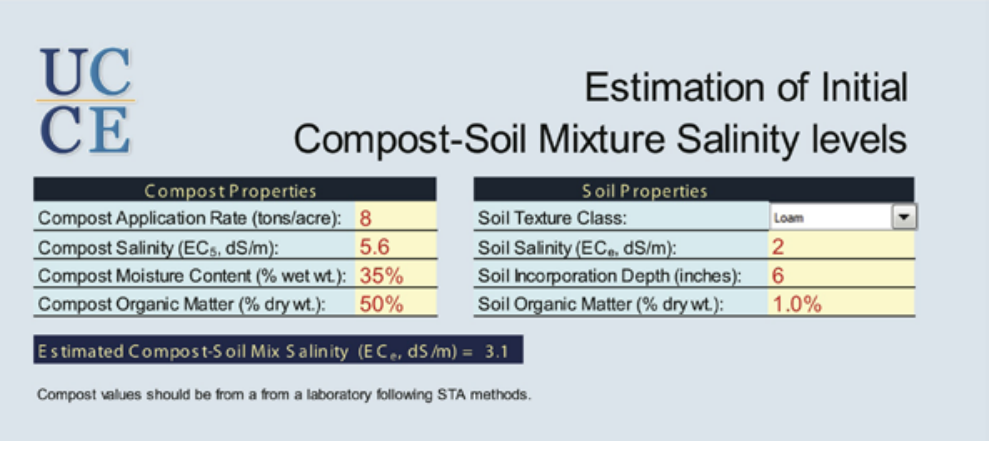

\section{Nitrogen}

Compost can supply considerable nitrogen to soils. Compost ammonium and nitrate are available for plant uptake on application, while organic nitrogen has to be mineralized to ammonium, or at least decomposed to simple and soluble organic forms, before it can be taken up (Näsholm et al. 2009). In general, high-C:N-ratio composts supply nitrogen more readily than low-C:N composts, but specific mineralization rates cannot be predicted with any precision. Because nitrogen is an important fertilizer, it is usually not toxic to crops at agronomic levels. High levels of ammonium can be phytotoxic, especially to seedlings, though susceptibility varies depending on the plant (Britto and Kronzucker 2002). Elevated nitrate in the soil has the potential to leach as a pollutant into groundwater, or it can be denitrified into nitrous oxide, a potent greenhouse gas. We should note that nitrogen losses to air and water may increase significantly if excessive amounts of nitrogen fertilizers are applied along with the compost (De Wever et al. 2002). The soil's available nitrogen status should be monitored, and fertilizer use adjusted to account for any nitrogen added with the compost. Wellcured compost contains more nitrogen as nitrate than as ammonium, but ammonium-rich composts can be used quite successfully, particularly if they are applied several weeks prior to planting.

\section{Total Phosphorus}

Phosphorus availability from composts compares favorably with that of conventional phosphorus fertilizers (Van Horn 1995; Sikora and Enkiri 2005). Elevated phosphorus levels in soils or mulches can, however, move off the field to pollute surface water (Crohn et al. 2013). To protect the environment and save money on fertilizers, growers should reduce their phosphorus fertilizer applications in proportion to the amount of phosphorus supplied by the compost.

\section{Stability}

A compost's stability is the degree to which its decomposition has slowed. Compost feedstock materials are made up of substances that break down at different rates. During composting, easily decomposable, or "labile," materials are eliminated, leaving more stable forms of carbon present in the compost when it is applied. Materials such as food wastes, biosolids, or manures are rich in fats, sugars, starches, and waxes. These labile materials are quickly converted by compost microbes to carbon dioxide and water, leaving behind resistant materials such as wood that contain mixtures of cellulose and lignin. It is common for labile materials to generate odors, tie up nitrogen, or release phytotoxic compounds as they break down. Compost producers eliminate odors, phytotoxins, and other detrimental factors by allowing their products to stabilize or "cure" for weeks or months before they are sent to market. Though the rapid decomposition associated with unstable composts may suppress certain soilborne plant pathogens, keep in mind that immature, insufficiently cured composts are otherwise not normally desirable (Zmora-Nahum et al. 2008). An insufficiently cured material will continue its rapid decay, generating phytotoxins, emitting odors, 
and possibly tying up valuable nitrogen. Unstable composts can stabilize after soil incorporation, but in such a case the grower may have to wait several weeks or months between application and planting (Aslam et al. 2008). The most direct means of assessing a compost's stability is to evaluate the rate at which $\mathrm{CO}_{2}$ is produced as the material breaks down under controlled moisture and temperature conditions. A material that generates less than $8 \mathrm{mg}$ $\mathrm{CO}_{2}$ per gram of organic matter per day during incubation at $135^{\circ} \mathrm{F}$ is sufficiently stable for agricultural use (Thompson et al. 2002). It should be noted that other stability tests are also available and that improvements in instrumentation may warrant the introduction of additional methods for measuring stability. If a compost smells "off" or "spoiled," it may be unstable and in need of more curing. Stable compost has a healthy, earthy smell.

\section{Table 4. Stability limits}

\begin{tabular}{|l|l|}
\hline Use & \multicolumn{1}{c|}{ Stability limit } \\
\hline Mulch & $\leq 8 \mathrm{mg} \mathrm{CO} 2 / \mathrm{g} \mathrm{OM} /$ day \\
\hline Soil amendment & $\leq 8 \mathrm{mg} \mathrm{CO} 2 / \mathrm{g} \mathrm{OM} /$ day \\
\hline
\end{tabular}

Table 5. Maturity

\begin{tabular}{|l|l|}
\hline Use & Maturity limit \\
\hline Mulch & $\geq 80 \%$ emergence \\
\hline Soil amendment & $\geq 80 \%$ emergence \\
\hline
\end{tabular}

Table 6. pH limits

\begin{tabular}{|l|c|}
\hline Use & pH limit \\
\hline Mulch & $6.0 \leq \mathrm{pH} \leq 8.5$ \\
\hline Soil amendment & $6.0 \leq \mathrm{pH} \leq 8.5$ \\
\hline
\end{tabular}

\section{Maturity}

Organic acids and other decomposition byproducts in immature composts can be toxic to plants. Germination tests provide a direct check for this effect. There is some discussion in the literature as to which are the best seeds to use to judge phytotoxicity. TMECC method 05-05-A specifies the use of salt-tolerant cucumber varieties (Thompson et al. 2002). Other researchers have found cucumber to be insensitive to toxins, and have suggested cress as a substitute (Aslam and VanderGheynst 2008), but a possible advantage to using cucumber is its relative insensitivity to salinity. The salinity of a compost is measured and assessed separately. For conventional agricultural uses, an $80 \%$ emergence rate from a cucumber seed test is considered acceptable (CCQC 2001; Thompson et al. 2002). The same compost will also be adequate for use as mulch on established grape vineyards and avocado orchards.

\section{pH}

Low-pH composts are in many cases incompletely cured, and may contain elevated concentrations of organic acids because of this. Organic acids are a routine byproduct of decomposition early in the composting process, but they should no longer be present at later stages. Since organic acids can be phytotoxic, low $\mathrm{pH}$ values are undesirable in a compost. The $\mathrm{pH}$ of a compost to be used in agriculture should fall between 6 and 8.5 as an indication of relative stability. Values near 7.5 are most typical. Most composts are slightly alkaline after curing, but some may be slightly acidic due to properties of their feedstock.

\section{Boron}

Boron is an important micronutrient. At elevated concentrations it can be phytotoxic, particularly when $\mathrm{pH}$ values and nitrogen concentrations are low, conditions that are most common in immature composts (Ryan and Chaney 1994). Boron toxicity is reduced by the presence of organic matter in compost, and boron salts can be managed through leaching (Purves and Mackenzie 1974). Boron was once a common additive for plywood and paper glues, so elevated levels may occur in composts that are derived from contaminated demolition debris, coal, or wood ash, but 
experience has shown that boron levels in composts rarely pose a phytotoxicity threat (Yermiyahu et al. 2001).

Avocado, lettuce, and grape are sensitive to boron, sharing a toxicity threshold of $0.5 \mathrm{ppm}$ (Hanson et al. 1993). Boron is less available in alkaline soils. For example, Brinton et al. (2008) studied a fly ash-amended compost and found 30 percent of total boron to be available at $\mathrm{pH} 6$, whereas only 10 percent was available at $\mathrm{pH}$ 7.6. A $100 \mathrm{ppm}$ limit is easily met by most compost products. Based on this ratio, and assuming that 40-percent-moisture compost contains $100 \mathrm{ppm}$ total boron, roughly 5.6 tons per acre at $\mathrm{pH} 6$ (or 17 tons per acre at $\mathrm{pH} 7.6$ ) could be expected to contribute 0.5 ppm boron to the soil. These numbers are only approximate and ignore soil and water background concentrations. Where boron is of concern due to high concentrations in irrigation water, lower-boron composts should be considered. As an added precaution, growers mulching grapes should seek stable composts with less boron content and a neutral to slightly alkaline $\mathrm{pH}$ profile. Soil boron concentrations should be monitored and leached if boron begins to accumulate.

Loading rates will be much higher for avocado and grape mulches, but the influence of mulches on soil chemistry will be much less since they are located above the soil. It is not known to what extent boron in mulches will leach into soils below or the extent to which avocado roots growing into mulches will be affected. Boron toxicity due to compost use is quite rare, however, and the coal ash compost studied by Brinton et al. (2008) may have been unusually soluble (Frank Shields, personal communication, 2009).

\section{Chloride}

Though chloride is a vital micronutrient, it can be toxic at elevated concentrations. Chloride toxicity usually results from elevated concentrations in irrigation water combined with insufficient leaching. Woody cultivars such as grapes and avocado are most susceptible to damage. Herbaceous crops such as lettuce and tomatoes are not. Strawberries are also sensitive to chloride. Soil status is normally assessed from a saturated extract and it is not possible to accurately predict the influence of compost chloride on
Table 7. Boron limits

\begin{tabular}{|l|l|}
\hline Use & Boron limit \\
\hline Mulch & $\leq 100 \mathrm{ppm}$ \\
\hline Soil amendment & $\leq 100 \mathrm{ppm}$ \\
\hline
\end{tabular}

Table 8. Chloride toxicity thresholds and proposed limits (less is better)

\begin{tabular}{|l|c|c|}
\hline Crop & $\begin{array}{c}\text { Toxicity threshold in } \\
\text { saturated extract }\end{array}$ & Chloride limit \\
\hline Avocado & meq/l & \% dry weight \\
\hline Lettuce & $5-7.5$ & $\leq 0.2$ \\
\hline Tomato & See ECe* & $\leq 1$ \\
\hline Grapes & See ECe* & $\leq 1$ \\
\hline Strawberry & $30-40$ & $\leq 1$ \\
\hline
\end{tabular}

SOURCE: Ayers and Westcott 1994; Hanson et al. 1993; Maas 1986.

* Lettuce and tomato do not suffer significant specific damage from chloride. Chloride does contribute to salinity (EC), however.

soil concentrations. The limits shown in table 8 are derived in part from market availability, and lower values are best. Many factors, including water management and soil conditions, affect chloride conditions. Use of compost must be considered as part of an overall salt-management plan.

\section{Sodium}

Excess sodium can lead to sodicity and phytotoxicity problems. Sodicity is the tendency of sodium to disperse soil particles so that soil structure is lost. Sodium toxicity results when plants take up sodium from the soil, rather than other needed nutrients, creating a nutritional imbalance. Compost is widely recommended for the remediation of sodic or saline soils but studies of the influence of compost on sodicity and salinity thus far are limited (Pessarakli and Szabolks 1999). With adequate water, compost use in soils has been shown either to leave soil sodicity unchanged (Walker and Bernal 2008) or to reduce soil sodicity (Avnimelech et al. 1994; Wright et al. 2008). 
Compost contributes organic matter to soils that assists in particle aggregation, helping to mitigate the harm of sodium additions to some extent. Compost organic matter can improve leaching efficiency for sodium and other salts. Composts also contain calcium and magnesium ions, the presence of which also helps offset the impact of sodium on soil structure (Amézketa 1999; Bronick and Lal 2005). A soil's sodium adsorption ratio (SAR) characterizes the balance between sodium and these other ions in the soil, but one cannot determine the SAR for a compost by itself, since the ions are measured differently in compost than in soil. As is the case with soil salinity, soil SAR values are determined from saturated paste extracts. The STA program does not require that laboratories report sodium, though most labs do. Measures of calcium and magnesium, however, are required. Total measures are usually presented, though available measures based on 1:5 compost-to-water extractions also appear. Even if SAR values were determined for composts, SAR estimates for soil-compost mixtures cannot be predicted with any confidence; the sodium, calcium, and magnesium in the compost interacts with the soil after incorporation, changing the proportions of these elements that are available in the resulting, amended soil.

Sodium can also be phytotoxic to woody plants such as avocado. Damage may at first be limited to the root system but it will in time reach the leaves unless soil sodium levels are reduced (Maas 1986). Lettuce and tomato are moderately susceptible to sodium damage, but management guidance for these crops is based on plant tissue analysis, not soil conditions (Ayers and Westcott 1994). Sodium content in plant tissues should be monitored where high sodium is a possible concern.

Compost containing more than 1 percent sodium (dry mass) is considered to be quite high in sodium, but such levels are not typical. Sodium risk is offset to some degree by improvements in infiltration and associated leaching associated with compost use, provided that sufficient water is applied. Soil conditions, water quality, other amendments, and management decisions will ultimately determine soil sodium levels, but when selecting a compost, a lower sodium value is preferred.

The Ag Index figure that appears on some compost analytical reports offers some protection against the collective excess sodium and chloride. $\mathrm{Ag}$ Index is determined as the compost macronutrient mass (grams of total $\mathrm{N}+\mathrm{P}_{2} \mathrm{O}_{5}+\mathrm{K}_{2} \mathrm{O}$ ) divided by its sodium chloride mass (grams $\mathrm{Na}+\mathrm{Cl}$ ). Values below 2 are considered poor, while values above 10 are considered excellent. The Ag Index has been widely used and we encourage compost purchasers to consider it. It appears on many STA reports and should be used together with EC values in making purchasing decisions.

\section{Man-made Inert Impurities}

Compost may contain glass, plastic, and other impurities. Plastic, in particular, can litter the soil and clog water systems. Soil is present in most composts and is not considered to be an impurity. Plastic should not be obviously visible in a quality compost. Plastic impurities weigh less than glass or metal and purchasers should use their own judgment is assessing whether plastic is present in acceptable levels within compost products under consideration. Both glass and plastic contaminants will accumulate in soils after repeated compost applications. Products having a lower impurity content are therefore preferred. Since impurities are visible, purchasers can also decide by direct inspection what is acceptable for particular purposes.

Table 9. Limits on manmade inert impurities

\begin{tabular}{|l|l|}
\hline Use & \multicolumn{1}{c|}{ Inerts } \\
\hline Mulch & $\leq 0.5 \%$ dry weight \\
\hline Soil amendment & $\leq 0.5 \%$ dry weight \\
\hline
\end{tabular}




\section{Particle Size Distribution}

There is room for great latitude in terms of particle size distribution where compost is used in agriculture. While the size of compost particles contributes to the effectiveness of a compost application, it is not usually a causal factor in crop damage in and of itself. Mulches should have particles that are larger than those in soil amendments. Large particles incorporated into a soil can tie up nutrients for too long, whereas an overabundance of small particles in a mulch can retard the movement of water into soils and also allow more weed development (Hartin and Crohn 2007). In erosion-control applications where the mulch is intended to encourage vegetation, smaller particles can perform well (Crohn et al. 2013).

\section{Safety: Metals}

Federal rules regulate the land application of biosolids, and the EPA conducted an extensive risk assessment to determine contaminant loading rates for this rule. The risk assessments assumed that biosolids would be applied at fertilizer rates for 100 years (US EPA 1993). California extends those limits to all composts and retains a chromium limit (Chaney 2004).

Biosolids standards were based on an assumed annual biosolids application of 4.46 ton/acre (10 Mg/ha) dry weight for 100 years, or a cumulative total of 446 ton/acre $(1,000 \mathrm{Mg} / \mathrm{ha})$. This loading rate is similar to actual application rates associated with the use of compost as a soil amendment, but is not directly applicable to areas where compost is applied as a mulch. The cumulative application rate of 446 ton/acre/century corresponds to 13.3 inches $(33.7 \mathrm{~cm})$ of $50 \%$ moisture compost with a moist bulk density of $1,000 \mathrm{lb} / \mathrm{yd}^{3}(593 \mathrm{~kg} /$

Table 10. Particle size limits

\begin{tabular}{|l|l|}
\hline Use & Size characteristics \\
\hline Soil amendment & $\begin{array}{r}\geq 95 \% \text { passing through a } 16 \mathrm{~mm} \text { screen } \\
\geq 70 \% \text { passing through a } 9.5 \mathrm{~mm} \text { screen }\end{array}$ \\
\hline Mulch to suppress weeds & $\begin{array}{r}\geq 99 \% \text { passing through a } 76 \mathrm{~mm} \text { screen } \\
\leq 25 \% \text { passing through a } 9.5 \mathrm{~mm} \text { screen }\end{array}$ \\
\hline $\begin{array}{l}\text { Vegetated erosion control } \\
\text { mulch }\end{array}$ & $\begin{array}{r}\geq 99 \% \text { passing through a } 76 \mathrm{~mm} \text { screen } \\
\geq 70 \% \text { passing through a } 16 \mathrm{~mm} \text { screen }\end{array}$ \\
\hline
\end{tabular}

$\mathrm{m}^{3}$ ), or, roughly, 13 1-inch compost applications. Adjustment of the numbers for metals to assume 1 -inch mulch applications at 4 -year intervals for 100 years would reduce current regulatory limits by a factor of 1.9 (Table 15). This is not a high application schedule for mulches. If mulches are applied at higher rates or more frequently than every 4 years, mulch metal limits lower than those shown in Table 11 should be considered.

\section{Safety: Pathogens}

State rules also apply federal biosolids regulations to all California composts. Numerical limits are enforced for fecal coliform and Salmonella sp. indicator organisms. Strict processing times, temperature rules, and record keeping requirements are included. There is no firm evidence that anyone has become ill as a result of the use of properly composted organic amendments or mulches (NRC 2002). Although pathogens are occasionally found in composts, it is not clear that they survive the composting process in any significant way. Crosscontamination from equipment is a likely explanation for positive pathogen tests (Wichuk and McCartney 2007).

The use of indicator organisms is a practical means for predicting the likelihood of presence of pathogens passed in fecal matter, whereas

Table 11. Maximum metal concentrations for California composts

\begin{tabular}{|l|c|c|}
\hline Metal constituent & $\begin{array}{c}\text { Compost } \\
\text { regulatory limit }\end{array}$ & $\begin{array}{c}\text { Equivalent } \\
\text { mulch limit }\end{array}$ \\
\hline Arsenic (As) & ppm & ppm \\
\hline Cadmium (Cd) & 41 & 22 \\
\hline Chromium (Cr) & 39 & 21 \\
\hline Copper (Cu) & 1,200 & 630 \\
\hline Lead (Pb) & 1,500 & 790 \\
\hline Mercury (Hg) & 300 & 160 \\
\hline Nickel (Ni) & 17 & 9 \\
\hline Selenium (Se) & 420 & 220 \\
\hline Zinc (Zn) & 36 & 19 \\
\hline
\end{tabular}


direct testing for all possible pathogens is economically unfeasible. Direct testing for a few specific pathogens does make sense, however, for crops that are normally eaten without cooking. Salmonella has been found on tomatoes, salad items, and nuts on a number of occasions in recent years, costing these industries millions of dollars in fines and lost product. More thorough sampling for Salmonella as well as testing for the dangerous E. coli O157:H7 bacteria is recommended for fresh produce grown close to the soil. Fresh leafy green produce such as lettuce, in particular, has an outer surface with gaps and crevices that can harbor pathogens and reduce the efficiency of washing (WPA 2013). To ensure proper collection of samples, composts applied to strawberries and lettuce should be sampled for analysis according to the protocols of the STA program.

\section{Conclusions}

The STA program provides reliable information on compost characteristics, but due to some differences in the measurement techniques for soil and compost, those measures usually are not directly comparable. Although the qualities of a compost also change significantly when it is added to a soil, an analytical description of the compost can be very useful in the selection and use of composts as soil amendments and mulches for different crops and conditions. A computer-based spreadsheet calculator is available for estimating the $\mathrm{EC}_{\mathrm{e}}$ of soil-compost mixtures. Composts can also be useful within potting media, but such use would require separate guidance documents. Growers should consider STA measures as well as the reputation of any local composters when deciding which products to purchase and apply. Once a compost is incorporated into the soil, growers can use traditional soil tests to measure soil qualities and document improvements or other changes to the soil.

\begin{tabular}{|c|c|}
\hline Use & Pathogen \\
\hline All & $\begin{array}{l}\text { Fecal coliforms }<1,000 \mathrm{MPN} \text { per gram total solids } \\
\text { Salmonella sp. }<3 \text { MPN per } 4 \text { grams total solids }\end{array}$ \\
\hline Fresh produce & $\begin{array}{l}\text { Salmonella sp. }<1 \text { MPN per } 30 \text { grams total solids } \\
\text { E. coli }<1 \text { MPN per } 30 \text { grams total solids }\end{array}$ \\
\hline
\end{tabular}

\section{References}

Alexander, R. 2001. Field guide to compost use. Bethesda, Maryland: U.S. Composting Council.

Amézketa, E. 1999. Soil aggregate stability: A review. Journal of Sustainable Agriculture. 14(2/3):83-151.

Aslam, D. N., and J. S. VanderGheynst. 2008. Predicting phytotoxicity of compost-amended soil from compost stability measurements. Environmental Engineering Science. 25(1):72-81.

Aslam, D. N., J. S. VanderGheynst, and T. R. Rumsey. 2008. Development of models for predicting carbon mineralization and associated phytotoxicity in compost-amended soil. Bioresource Technology. 99(18):8735-8741.

Avnimelech, D., Y. Shkedy, M. Kochva, and Y. Yotal. 1994. The use of compost for reclamation of saline and alkaline soils. Compost Science and Utilization. 2:6-11.

Ayers, R. S., and D. W. Westcott. 1994. Water quality for agriculture. Rome: Food and Agroculture Organization.

Bernal, M. P., J. A. Alburquerque, and R. Moral. 2009. Composting of animal manures and chemical criteria for compost maturity assessment. A review. Bioresource Technology. 100(22):5444-5453.

Brinton, W. F., E. Evans, and D. Blewett. 2008. Extractability, plant yield and toxicity thresholds for boron in compost. Compost Science and Utilization. 16(2):114-118.

Britto, D. T., and H. J. Kronzucker. 2002. $\mathrm{NH}_{4}^{+}$toxicity in higher plants: A critical review. Journal of Plant Physiology. 159(6):567-584.

Bronick, C. J., and R. Lal. 2005. Soil structure and management: A review. Geoderma. 124(1-2):3-22.

Bruun, S., J. Luxhøi, J. Magid, A. de Neergaard, and L. S. Jensen. 2006. A nitrogen mineralization model based on relationships for gross mineralization and immobilization. Soil Biology and Biochemistry. 38(9):2712-2721. 
CCQC (California Compost Quality Council). 2001. Compost maturity index. Nevada City, California: California Compost Quality Council.

Chaney, R. L. 2004. Use and abuse of part 503 requirements: Improved risk assessment for contaminants in non-biosolids by-products (abstract). Romeo, Michigan.

Crohn, D. M., V. N. Chaganti, and N. Reddy. 2013. Composts as post-fire erosion control treatments and their effect on runoff water quality. Transactions of the ASABE. 56(2): In press.

De Wever, H., S. Mussen, and R. Merckx. 2002. Dynamics of trace gas production following compost and $\mathrm{NO}_{3}$ - amendments to soil at different initial $\mathrm{TOC} / \mathrm{NO}_{3}-$ ratios. Soil Biology and Biochemistry. 34(11):1583-1591.

Hanson, B., S. R. Grattan, and A. Fulton. 1993. Agricultural salinity and drainage. Davis, California: Cooperative Extension, Dept. of Land, Air, and Water Resources.

Hartin, J., and D. Crohn. 2007. Compost use for landscape and environmental enhancement. Sacramento: California Integrated Waste Management Board.

Leege, P. B. 1998. Introduction of test methods for the examination of composting and compost. In S. L. Brown, J. S. Angle, and L. W. Jacobs (eds.), Beneficial co-utilization of agricultural, municipal and industrial by-products. Netherlands: Springer. Pp. 269-282.

Maas, E. V. 1986. Salt tolerance of plants. In B. R. Christie (ed.), Handbook of plant science in agriculture. Boca Raton, Florida: CRC Press. Pp. 57-76.

Näsholm, T., Kielland, K., and Ganeteg, U. 2009. Uptake of organic nitrogen by plants. New Phytologist. 182(1):31-48.

NRC. 2002. Biosolids applied to land. National Research Council. Washington, D.C.: National Academies Press.

Paul, E. A. 2007. Soil microbiology, ecology, and biochemistry. Third ed. Burlington, Massachussets: Academic Press.
Pessarakli, M., and I. Szabolks. 1999. Soil salinity and sodicity as particular plant/crop stress factors. In M. Pessarakli (ed.), Handbook of plant and soil stress. New York: Marcel Dekker, Inc. Pp. 1-15.

Purves, D., and E. J. Mackenzie. 1974. Phytotoxicity due to boron in municipal compost. Plant and Soil. 40(1):231-235.

Reddy, N., and D. M. Crohn. 2012. Compost induced soil salinity: A new prediction method and its effect on plant growth. Compost Science and Utilization. 20(3):133-140.

Ryan, J. A., and R. L. Chaney. 1994. Heavy metals and toxic organic pollutants in msw-composts: Research results on phytoavailability, bioavailability, fate, etc. PB-94-155348/XAB; EPA--600/A-94/030 United StatesTue Feb 12 17:54:11 EST 2008NTISGRA; GRA-9432871; EDB-94-090795English.

Rynk, R., M. Van de Kamp, G. B. Willson, M. E. Singley, T. L. Richard, J. J. Kolega, F. R. Gouin, L. Laliberty, D. Kay, D. W. Murphy, H. A. J. Hoitink, and W. F. Brinton. 1992. On-farm composting handbook. NRAES-54. Ithaca, New York: Northeast Regional Agricultural Engineering Service.

Shannon, M. C., and C. M. Grieve. 1998. Tolerance of vegetable crops to salinity. Scientia Horticulturae. 78(1-4):5-38.

Sikora, L. J., and N. K. Enkiri. 2005. Comparison of phosphorus uptake from poultry litter compost with triple superphosphate in codorus soil. Agronomy Journal. 97(3):668-673.

Thompson, W. H., P. B. Leege, P. D. Millner, and M. E. Watson. 2002. TMECC: Test methods for the examination of composting and compost. Washington, D.C.: U.S. Composting Council Research and Education Foundation and the United States Department of Agriculture.

USEPA. 1993. 40 CFR Part 503: Standards for use of disposal of sewage sludge; final rules. Environmental Protection Agency. Federal Register. 58(32):9248-9415.

Van Horn, M. 1995. Compost production and utilization: A grower's guide. No. 21514. Richmond, California: UC ANR Publications. 
Walker, D. J., and M. P. Bernal. 2008. The effects of olive mill waste compost and poultry manure on the availability and plant uptake of nutrients in a highly saline soil. Bioresource Technology. 99(2):396-403.

WGA. 2013. Commodity specific food safety guidelines, August 2, 2013. Irvine, California: Western Growers Association. www.caleafygreens.ca.gov/sites/default/files/California\%20 LGMA\%20metrics\%2008\%2026\%2013\%20\%20Final.pdf.

Wichuk, K. M., and D. McCartney. 2007. A review of the effectiveness of current time-temperature regulations on pathogen inactivation during composting. Journal of Environmental Engineering and Science. 6(5):573-586.

\section{For More Information}

To order or obtain ANR publications and other products, visit the ANR Communication Services online catalog at http://anrcatalog.ucanr.edu/ or phone 1-800-994-8849. You can also place orders by mail or FAX, or request a printed catalog of our products from

University of California

Agriculture and Natural Resources

Communication Services

1301 S. 46th Street

Building 478 - MC 3580

Richmond, CA 94804-4600

Telephone 1-800-994-8849, 510-665-2195

FAX 510-665-3427

E-mail: anrcatalog@ucanr.edu

(C2016 The Regents of the University of California. This work is licensed under the Creative Commons Attribution-NonCommercial-NoDerivatives 4.0 International License. To view a copy of this license, visit http://creativecommons.org/licenses/by-nc-nd/4.0/ or send a letter to Creative Commons, PO Box 1866, Mountain View, CA 94042, USA.

Publication 8514

ISBN-13: 978-1-60107-892-6

The University of California, Division of Agriculture and Natural Resources (UC ANR) prohibits discrimination against or harassment of any person in any of its programs or activities on the basis of race, color, national origin, religion, sex, gender, gender expression, gender identity, pregnancy (which includes pregnancy, childbirth, and medical conditions related to pregnancy or childbirth), physical or mental disability, medical condition (cancer related or genetic characteristics), genetic information (including family medical history), ancestry, marital status, age, sexual orientation, citizenship, status as a protected veteran or service in the uniformed services (as defined by the Uniformed Services Employment and Reemployment Rights Act of 1994 [USERRA]), as well as state military and naval service.
Wright, A. L., T. L. Provin, F. M. Hons, D. A. Zuberer, and R. H. White. 2008. Compost impacts on sodicity and salinity in a sandy loam turf grass soil. Compost Science and Utilization. 16(1):30-35.

Yermiyahu, U., R. Keren, and Y. Chen. 2001. Effect of composted organic matter on boron uptake by plants. Soil Science Society of America Journal. 65(5):1436-1441.

Zmora-Nahum, S., M. Danon, Y. Hadar, and Y. Chen. 2008. Compost curing reduces suppression of plant diseases. Compost Science and Utilization. 16(4):250-256.

UC ANR policy prohibits retaliation against any employee or person in any of its programs or activities for bringing a complaint of discrimination or harassment. UC ANR policy also prohibits retaliation against a person who assists someone with a complaint of discrimination or harassment, or participates in any manner in an investigation or resolution of a complaint of discrimination or harassment. Retaliation includes threats, intimidation, reprisals, and/or adverse actions related to any of its programs or activities.

UC ANR is an Equal Opportunity/Affirmative Action Employer. All qualified applicants will receive consideration for employment and/or participation in any of its programs or activities without regard to race, color, religion, sex, national origin, disability, age or protected veteran status.

University policy is intended to be consistent with the provisions of applicable State and Federal laws.

Inquiries regarding the University's equal employment opportunity policies may be directed to: John Sims, Affirmative Action Contact and Title IX Officer, University of California, Agriculture and Natural Resources, 2801 Second Street, Davis, CA 95618, (530) 750-1397. Email: jsims@ucanr.edu. Website: http://ucanr.edu/sites/anrstaff/Diversity/Affirmative_Action/.

To simplify information, trade names of products have been used. No endorsement of named or illustrated products is intended, nor is criticism implied of similar products that are not mentioned or illustrated.

An electronic copy of this publication can be found at the ANR Communication Services catalog website, http://anrcatalog.ucanr.edu/.

UC This publication has been anonymously peer reviewed for technical accuracy REVIEWED by University of California scientists and other qualified professionals. This review process was managed by ANR Associate Editor for Agronomy and Range Sciences.

web-09/16-SB/CR 